\title{
DOI https://doi.org/10.30525/978-9934-26-044-5-17
}

\section{ТАБОРИ АКТИВНОЇ РЕАБІЛІТАЦІЇ ЯК ВАЖЛИВА СКЛАДОВА СУЧАСНИХ ФІЗКУЛЬТУРНО-СПОРТИВНИХ ПОСЛУГ ДЛЯ ВІЙСЬКОВОСЛУЖБОВЦІВ З НАСЛІДКАМИ БОЙОВОЇ ТРАВМИ}

\author{
Крушинська Н. М. \\ старший викладач кафедри професійного, \\ неолімпійського та адаптивного спорту \\ Національний університет фізичного виховання і спорту Украӥни \\ м. Київ, Україна
}

Юденко О. В. кандидат педагогічних наук, доиент кафедри професійного, неолімпійського та адаптивного спорту Національний університет фізичного виховання і спорту України м. Київ, Україна

\section{Партика C. C.}

науковий співробітник науково-дослідної лабораторії науково-дослідного центр проблем фізичного виховання, спеціальної фізичної підготовки і спорту Начіональний університет оборони України імені Івана Черняховського, капітан м. Київ, Украӥна

Головних питанням сьогодення $є$ «відсутність системного підходу до реабілітації часників бойових дій та мирного населення». Ю.О. Гріненко здійснив аналіз, за результатами якого зафіксовано, що в Україні систематично зростає кількість військовослужбовців ATO/OОС, учасників бойових дій із наслідками бойової травми (далі БТ), які потребують фізичного відновлення; «реабілітація має бути комплексна: медична, фізична i психологічна; процес має бути безперервним і фаховим». Це підтверджує актуальність нашої роботи.

У відповідності до «Закону України «Про реабілітацію осіб 3 інвалідністю в Україні»« «фізкультурно-спортивна реабілітація» (далі ФСР) - це «система заходів, розроблених із застосуванням фізичних вправ для відновлення здоров'я особи та спрямованих на відновлення i компенсацію за допомогою занять фізичною культурою і спортом 
функціональних можливостей iіï організму для покращення фізичного i психологічного стану».

Табори активної реабілітації (далі ТАР) - один з методів відновлення фізичного та соціального стану людини після ураження ОРА або сенсорних функцій організму, внаслідок травми, поранення чи захворювання; методику винайшли у Швеції у 70-х роках, а з 90-х іiі почала працювати в Україні Група АР [2; 3]. Головним принцип «рівний-рівному». У ТАР запрошуються тренери, які мають такі самі травми, як і учасники $[2 ; 3]$. Основними складовими процесу ТАР $\epsilon$ фізична, психологічна та соціальна реабілітація. Головна мета: «досягнення людиною 3 функціональними ураженнями, максимальної незалежності від сторонньої допомоги, покращення якості життя» [2; 3]. Найулюбленіше місце проведення ТАР $є$ Західний реабілітаційноспортивний центр НКСУ осіб з інвалідністю (с. Яворів, Львівської обл.: www.westsportcenter.com.ua).

В. Пчолкін (виконавчий директор ГО «Група активної реабілітації», гравець команди 3 регбі на візках Київської обл.), зазначає, що «обов'язково в рамках ТАР влаштовують дискотеки під час яких демонструються різні «фішки» на візках; в перші дні учасники насторожено споглядають, а далі із зацікавленістю намагаються копіювати наші дії». Зазвичай люди часто соромляться своєї інвалідності, не викладаються світлини у соціальних мережах, ми ж навпаки робимо багато гарних фото, під ними з'являються коментарі підтримки, що дуже підбадьорює та надихає на подальші дії [3]. В. Пчолкін [3] зазначає, що «в Україні є дуже професійні нейрохірурги, вони круто роблять складні операції, але вони не завжди цікавляться, що 3 пацієнтом відбувається далі. Нажаль, часто фізичних терапевтів лікарі не сприймають серйозно». Але при цьому він наголошує на тому, що для ого «щоб жити активно - треба цього дійсно хотіти, докладати зусиль, знати свої права, відстоювати їх» [3].

В ТАР для учасників працюють інструктори активної реабілітаціїлюди з інвалідністю, які готові поділитися своїми знаннями та досвідом за принципом «рівний-рівному»; фахівиі фізичної реабілітації / терапіїпроводитимуть групові та індивідуальні заняття із загально-фізичної підготовки, ЛФК та ерготерапії; психологи - проводитимуть індивідуальні консультації та групові заняття; асистенти реабілітолога, які отримали необхідні навички, i під проводом інструкторів допомагають опанувати програму ТАР; аніматор, арттерапевт, працетерапевт - забезпечать програму побутової та дозвіллєвої терапії; тренери-інструктори з паралімпійської підготовки - проводитимуть заняття з різних спортивних дисциплін [2; 3]. Програма ТАР: 3 щоденних 
тренування з різних дисциплін, включаючи спортивні дисципліни (літніх та зимових: настільний теніс, стрільба з луку, боча, спортивний більярд, крокет, дартс, аеробіка, лижі - незалежно від ступеню та форми функціональних порушень), заняття з ЛФК ЗФП та ерготерапії; заняття 3 психологом; бесіди із соціальних / юридичних питань; дні активного відпочинку; майстер-класи 3 арт-терапевтами; участь у вечірках. Важливим фактором відновлення військовослужбовців із наслідками БТ $\epsilon$ нормальне спілкування з рідними та близькими, відчуття їх підтримки та всебічної допомоги.
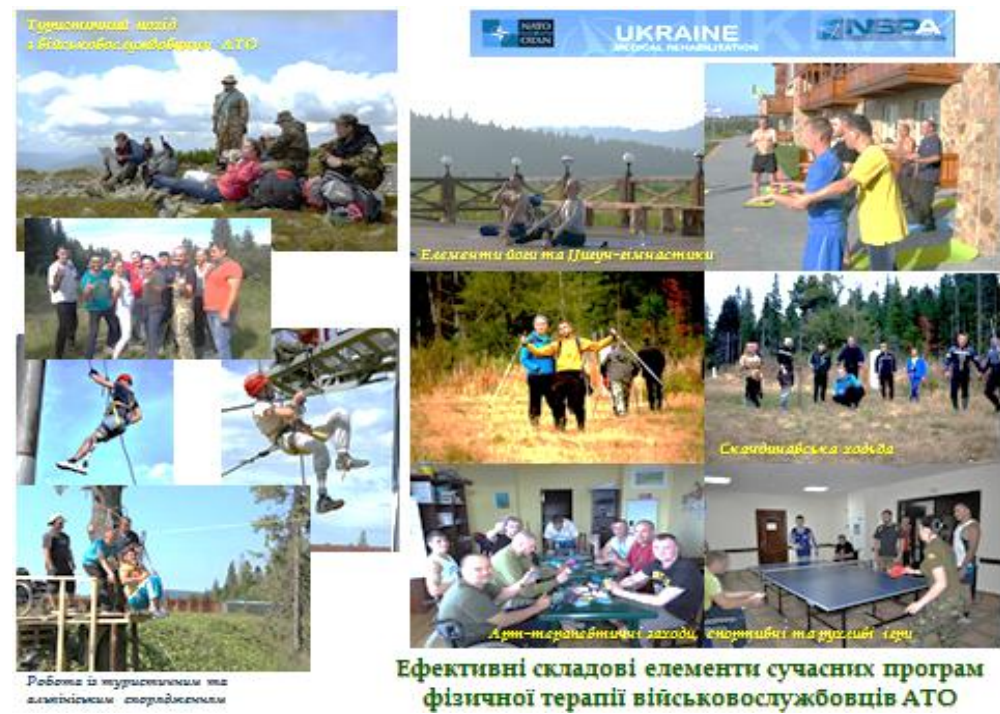

Рис. 1. Складові рухової активності в таборах активної реабілітації учасників військових локальних конфліктів із наслідками бойової травми (за О.В. Юденко та В.В. Правдивим)

Учасником програми ТАР «Повернення до життя» можуть бути учасники бойових дій в зоні АТО, які мають порушення ОРА, в т.ч. ампутації кінцівок, порушення зору, слуху, травму хребта з ураженням спинного мозку, ЧМТ тощо, і які не мають відкритих ран та суворих протипоказань до фізичних навантажень [2; 3]. В межах проведення ФСР військові часто звертаються до різних видів фізкультурнооздоровчої діяльності, а популярними засобами є: легка атлетика, футбол, баскетбол, волейбол, бадмінтон, бочча, петанк, настільний 
теніс, більярд, танцювальна терапія, туристичні походи різного напрямку та складності; лікувально-оздоровче плавання та аква-фітнес; інтелектуальні ігри; спортивне орієнтування, йога, цигун тощо [2; 3]. Багато уваги слід приділяти лікувальній ходьбі, теренкуру, ходьбі на лижах, ближньому туризму.

В.В. Правдивий, О.В. Юденко та Я.В. Кравченко [5; 6] зазначають, що «різновиди сучасної зброї значно від тих вражаючих факторів, які виникають у людей в мирному житті, тому ці аспекти слід враховувати, а також в екстреному режимі переймати досвід провідних країн світу, які тривалий час працюють 3 військовослужбовцями із наслідками бойової травми - учасниками бойових дій, таких як Ізраїль, США, Великобританія та інші країни НАТО»; «програми корекційновідновлювальної терапії повинні включати одночасно декілька напрямків (впливаючи на фізичне, психічне та соціальне здоров'я особистості, сприяти соціальній та професійній адаптації), «слід враховувати психо-емоційний та соціальний стан пацієнтів, ступінь ураження організму, характер та умови отримання БТ» [5]. Для окремих людей, внаслідок їх особистісної реакції на БТ, спортивнооздоровча діяльність $є$ чи не єдиною доступною та простою дією, що поєднує їх з мирним життям, родиною та близькими.

О. Федорович [7] вивчала питання розвитку ТАР та їх особливості роботи для осіб з ураженнями ОРА. Фахівці констатують, що важливим досягненням на сьогодні $\epsilon$ те, що в межах угоди співпраці України із НАТО підвищено кваліфікацію 8050 українських фахівців з питань реабілітації та надано допомогу у реформуванні системи військовомедичного забезпечення $[6,7]$.

У рамках програми ТАР «Повернення до життя» за 2016-2018 рр. пройшли 2-ох тижневі реабілітаційні табори понад 170 військовослужбовців учасників АТО/ООС. Робота в ТАР для військовослужбовців із наслідками БТ проводиться через паралімпійську методологію скерування до подальших систематичних занять ФКіС, в секціях ФСР та орієнтування на подальшу професійну адаптацію. В.В. Правдивий [5] констатує, що на сьогодні серед військовослужбовців із насідками БТ популярною є програма розроблена разом із фахівцями НАТО та волонтерами України - «Повернення до життя».

Отже, ТАР $\epsilon$ ефективною складовою сучасної ФСР військовослужбовців із наслідками БТ, їх соціальної адаптації. Популярними $є$ засоби легкої атлетики та кросфіту, Body\&Mind Fitness, туризм, спортивні ігри та арт-терапевтичні техніки для відновлення здоров'я учасників АТО/OOC. 


\section{Література:}

1. Ефективність використання йога-терапії в комплексних програмах відновлення здоров'я чоловіків II зрілого віку із захворюваннями ОРА (2019) / О.В. Юденко. Збір. наук. матер. інтерент-конф. «Проблеми та перспективи розвитку сучасної науки» Вінниця. 8; 56-63.

2. Офіційний сайт «ВГО «Національна Асамблея людей 3 інвалідністю»« : Учаснику програми АР «Повернення до життя» (Що таке активна реабілітація?). URL : https://naiu.org.ua/nato/uchasnykuprogramy-aktyvnoyi-reabilitatsiyi-povernennya-do-zhyttya/

3. Свій Серед Своїх: регбі, бізнес, активізм в інвалідному візку. 10.12.2019. URL : https://www.ua.undp.org/content/ukraine/uk/home/ presscenter/articles/2019

4. Спортивне орієнтування як ефективна складова комплексної фізкультурно-спортивної реабілітації ветеранів-військовослужбовців АТО і ОСС в Україні (2020) / М.О. Тимощук, О.В. Юденко. Теоретикометодичні аспекти фізичної культури і спорту : матер. наук.-практ. конф. Івано-Франківськ-Київ: НУФВСУ. С. 88-96.

5. Сучасні підходи до побудови програм фізичної терапії військовослужбовців АТО на поліклінічному етапі (2019) / О.В. Юденко, В.В. Правдивий. ХХХ Між. Інтернет-конф. : Сучасні досягнення науки і техніки. 57-66.

6. Сучасні підходи до формування програм фізичної терапії військовослужбовців АТО 3 травмами нижніх кінцівок (2019) / О.В. Юденко, Я.В. Кравченко Науковий часопис. НПУ імені М.П. Драгоманова. Серія 15. «Науково-педагогічні проблеми фізичної культури: зб. наук. праць. К. : НПУ імені М.П. Драгоманова. Вип. 3 (115 C)19. C. 35-39.

7. Федорович О. Організація проведення таборів активної реабілітації для спинальних хворих (2007) Молода спортивна наука Украӥни : зб. наук. пр. з галузі фіз. культ. та спорту. Львів. Вип. 11, T. 2. C. $342-345$. 